\title{
Mempertahankan Eksistensi Jamu Tradisional melalui Perubahan Desain Pengemasan dan Pemasaran
}

\author{
Harsa Wara Prabawa, Andhin Dyas Fitriani \\ Universitas Pendidikan Indonesia \\ email: harsawara@upi.edu
}

\begin{abstract}
Abstrak
Jamu diyakini digunakan sebagai sarana untuk meningkatkan kebugaran, untuk menyembuhkan penyakit, dan untuk menjaga kecantikan. Saat ini, jamu bahkan dikonsumsi sebagai pengobatan komplementer dan alternatif (complementary and alternative medicine - CAM), terapi, dan bahkan untuk pengobatan kondisi parah seperti gagal ginjal dan diabetes. Namun bukan berarti industri jamu tidak memiliki kendala, terutama jika dikaitkan dengan eksistensi jamu tradisional. Permasalahan sebagian besar pelaku usaha jamu tradisional adalah penyajian jamu tradisional sendiri masih cenderung monoton dalam hal pengemasan dan kemasan, terutama jika ditinjau dari aspek visual. Permasalahan cara menjual dan segmen pasar yang dituju juga menjadi alasan kenapa jamu tradisional masih belum dapat bersaing secara baik dalam pasar yang tersedia. Pengabdian ini secara umum bertujuan untuk meningkatkan keterampilan pengusaha jamu tradisional di kecamatan Cimenyan terutama dalam hal yang berkaitan dengan strategi pemasaran dari produk jamu tradisional. Oleh karenanya, kegiatan pengabdian ini menargetkan beberapa pembenahan dalam penanganan masalah kemasan produk, yang diantaranya menyangkut proses edukasi dan pendampingan dalam perluasan pemasaran. Hasil diperoleh dari kegiatan pengabdian ini cukup memuaskan. Setidaknya jika ditinjau dari sisi perluasan segment pasar dan peningkatan volume penjualan yang pada akhirnya berdampak pada peningkatan pendapatan. Dalam kurun waktu tiga bulan pertama, peningkatan omset penjualan jamu tercatat sebesar lebih dari dua kali lipat dibandingkan dengan saat penjualan regular.
\end{abstract}

Kata kunci: jamu tradisional, desain pengemasan, pemasaran

\section{PENDAHULUAN}

Jamu merupakan warisan budaya bangsa yang sudah digunakan secara turun menurun. Perkembangan ilmu pengetahuan dan teknologi serta globalisasi kemudian menjadikan jamu mulai berkembang. Beberapa faktor pendorong terjadinya peningkatan penggunaan jamu sebagai obat tradisional adalah adanya harapan hidup yang lebih panjang pada saat meningkatnya prevalensi penyakit-penyakit kronis, adanya kegagalan penggunaan dan efek samping obat-obat kimia, serta semakin luasnya akses informasi mengenai obat tradisional di seluruh dunia (Prabawani, 2017). Indonesia sendiri sebenarnya memiliki keunggulan dalam hal pengembangan jamu dengan 9.600 jenis tanaman obat yang dapat digunakan sebagai bahan dasar jamu (Muslimin, et al., 2009). Inilah yang menjadikan jamu begitu dikenal sebagai produk asli Indonesia dan telah dikenal hingga ke manca negara (Neubauer, 2012).

Dalam sejarahnya, jamu telah digunakan oleh keluarga kerajaan untuk meningkatkan kebugaran, untuk menyembuhkan penyakit, dan untuk menjaga kecantikan (Zuraina et al., 1990 dalam Prabawani, 2017). Saat ini, jamu bahkan dikonsumsi sebagai pengobatan komplementer dan alternatif (complementary and alternative medicine - CAM) (Nissen \& Evans, 2012), terapi, dan bahkan untuk 
mengobati kondisi parah seperti gagal ginjal dan diabetes (Tuschinsky, 1995 dalam Prabawani, 2017). Selain itu, Jamu menyediakan banyak zat besi, yang kekurangannya merupakan masalah besar di Indonesia dalam kaitannya dengan peran besi dalam hal-hal yang berhubungan dengan produktivitas, pertumbuhan, daya tahan tubuh, serta kesehatan kehamilan (Kodyat, Kosen, \& De Pee, 1998 dalam Prabawani, 2017). Sebagian berpendapat, jamu tidak masuk ke dalam kategori obat. Sebagian lainnya menganggap, tanpa tambahan zat kimia, jamu sudah dapat diklasifikasikan sebagai phytopharmacy dan dapat disetarakan dengan obat-obatan sintetik atau obat obat kimia yang ditingkatkan (chemically enhanced medicines) (Dean \& McGuire, 2005). Namun, jika dibandingkan dengan obat-obatan konvensional, Jamu lebih terjangkau dari sisi harga, lebih mudah tersedia, dan memiliki efek samping yang lebih sedikit (Muslimin, et al., 2009).

Pasar industri jamu Indonesia telah menunjukkan pertumbuhan yang signifikan dengan nilai penjualan mencapai Rp 6 triliun, telah menciptakan tiga juta lapangan kerja, dan dengan daerah konsumen terbesar di pulau jawa mencapai $60 \%$ pada tahun

2007 (GP Jamu, 2008 dalam Muslimin, et al., 2009). Dengan keunggulan komparatif yang dimiliki sebagai industri berbasis sumberdaya lokal, KADIN dalam visi 2030 dan

Road Map Industri Nasional merekomendasikan jamu sebagai klaster industri unggulan penggerak pencipta lapangan kerja dan penurun angka kemiskinan dan atas dasar kearifan lokal dan potensi yang dimiliki produk Jamu, Kementerian Koordinator Bidang Ekonomi telah mencanangkan gerakan "Jamu Brand Indonesia" sebagai bagian dari kegiatan menyatukan merek jamu dalam satu payung Brand Indonesia (Muslimin, et al., 2009).

Namun di tengah keberhasilan tersebut masih banyak kendala yang dihadapi oleh industri jamu nasional. Membanjirnya produk jamu impor yang dengan mudah ditemukan di pasar dalam negeri memberikan dampak yang rentan terhadap persaingan dan citra jamu terutama bagi industri skala kecil. Belum termasuk permasalahan internal sebagian besar pelaku usaha jamu tradisional yang cenderung masih concern pada penstabilan wirausaha yang baru dimulai atau bahkan dalam rangka menambah income keluarga. Di sisi lain, penyajian jamu tradisional sendiri masih cenderung monoton dalam hal kemasan, terutama jika ditinjau dari aspek visual (Natadjaja, Tripoli, \& Wahyono, 2013). Permasalahan cara menjual dan segmen pasar yang dituju juga menjadi hal lain yang menambah deretan panjang alasan kenapa jamu tradisional masih belum dapat bersaing secara baik dalam pasar yang tersedia. Dalam konteks ini, menjadi hal yang penting untuk dapat mengoptimalkan segmen penjual jamu tradisional agar dapat lebih dikenal oleh pasar.

Dari sisi pengemasan, misalnya, sudah cukup awam diketahui bahwa sebagian penjual jamu tradisional yang menggunakan botol plastik bekas air mineral sebagai media penyimpanan jamu tradisionalnya (Tari, 2015). Padahal peruntukan botol air mineral termasuk dispossible, yakni tidak boleh digunakan lagi setelah isinya habis. Untuk diisi ulang air putih saja sangat tidak dianjurkan, apalagi digunakan untuk wadah jamu. Dalam hal penyajian dan pemasaran, juga terkesan cukup klasik karena cenderung terbatas hanya melingkupi segmen paruhbaya dan sebagian besarnya adalah wanita. Padahal, bisa jadi kebutuhan terhadap jamu tradisional terdapat pada segmen anak muda yang lebih mudah untuk terprovokasi dengan tampilan dan kemasan.

Kemasan dan pemasaran merupakan "pemicu" terjadinya transaksi jual beli, karena ia langsung berhadapan dengan konsumen. Karena itu kemasan dan cara memasarkan harus dapat mempengaruhi konsumen untuk memberikan respon positif. Dampak paling logisnya adalah kemasan dan pemasaran yang baik akan mengoptimalkan keuntungan. 
Nah, berikut adalah beberapa faktor yang dianggap perlu dipertimbangkan dalam kaitannya dengan pemasaran serta kondisi aktual yang ada pada pengusaha jamu tradisional di Kecamatan Cimenyan:

Pendistribusian

Dari sisi pendistribusian, sejauh ini pengusaha jamu tradisional di kecamatan Cimenyan hanya menjual produk jamu tradisionalnya dari rumah ke rumah, dengan media pemesanan via handphone. Jika dalam satu atau beberapa hari tidak ada pemesanan, maka jamu tidak akan diproduksi

Identitas

Dikarenakan pengemasan yang cenderung tidak membuat perbedaan dengan produk sejenis lainnya yang dipasarkan, pengusaha jamu tradisional di kecamatan Cimenyan belum dapat menampilkan identitas pada produk jamu tradisional yang dijual.

\section{Promosi}

Karena berbasis penjualan dari rumah ke rumah, pengusaha jamu tradisional di kecamatan Cimenyan, cenderung mengabaikan aspek promosi. Kalaupun ada, cerderung bersifat pasif. Hanya mengandalkan informasi dari mulut ke mulut antar sesama pembeli. Dengan media promosi yang terbatas, tentunya sejuah ini belum ada peningkatan yang cukup signifikan dari sisi kuantitas penjualan hariannya

Keberhasilan penjualan tergantung pada citra yang diciptakan oleh kemasan dan cara memasarkan produk tersebut. Penampilan harus dibuat sedemikian rupa agar konsumen dapat memberikan reaksi spontan, baik secara sadar ataupun tidak.

Pengabdian ini secara umum bertujuan untuk meningkatkan keterampilan pengusaha jamu tradisional di kecamatan Cimenyan terutama dalam hal yang berkaitan dengan desain kemasan dan strategi pemasaran dari produk jamu tradisional yang dijajakan selama ini. Oleh karenanya, kegiatan pengabdian ini menargetkan beberapa pembenahan dalam penanganan masalah kemasan produk, yang diantaranya menyangkut proses edukasi dan pendampingan dalam perluasan pemasaran berbasis teknologi informasi serta melakukan proses edukasi terhadap desain kemasan yang berorientasi pada perluasan segmen konsumen.

Berdasarkan hasil evaluasi tersebut, diperlukan beberapa rencana solusi berbasis pemberdayaan masyarakat yang akan dilakukan pada pengusaha jamu tradisional di kecamatan Cimenyan adalah:

1. Edukasi dan pendampingan dalam perluasan pemasaran

Secara umum, strategi pemasaran dilakukan terbagi ke dalam 2 (dua) kategori utama, yaitu segmentasi pasar dan market targeting. Proses edukasi keduanya mengacu pada pendapat Dharmmesta (2002), dimana segmentasi pasar dapat dimaknai sebagai kegiatan mempartisi pasar (yang pada awalnya bersifat heterogen) ke dalam suatu satuan/segmen yang cenderung bersifat homogen. Setidaknya terdapat beberapa faktor yang dapat dijadikan acuan dalam mempartisi pasar, diantaranya adalah demografis (seperti umur, jenis kelamin, pendidikan dan lain sebagainya); tingkat penghasilan; faktor sosiologis (seperti kelompok budaya, kelas sosial dan lain sebagainya) serta faktor geografis.

Dharmmesta (2002) mengajukan setidaknya mengajukan 3 (tiga) kecenderungan market targeting, diantaranya adalah: 
a. Differentiated Marketing (pemasaran serba beda), pola targeting tipe ini lebih mengarahkan penjual untuk melakukan penyesuaian produk berdasarkan hasil segmentasi pasar. Penjual diharapkan mampu menciptakan dan mengembangkan banyak jenis produk yang berbeda sesuai dengan banyaknya segmen yang tersedia.

b. Undifferentiated Marketing (pemasaran serba sama), pola targeting tipe ini cenderung mengabaikan perbedaan dalam segmen pasar, dengan kata lain penjual akan memasarkan suatu produk tunggal namun ditujukan untuk bisa memenuhi kebutuhan setiap segmen yang tersedia.

c. Concentrated Marketing (pemasaran terpusat), pola targeting tipe ini lebih meminta penjual untuk fokus dalam menggarap satu atau beberapa segmen saja.

Di tahap awal, pengabdian ini diarahkan untuk memilih strategi pemasaran serba sama (undifferentiated marketing), dengan alasan lebih memudahkan penjual jamu untuk memproduksi produk jamunya.

Dampak paling logis dari penetapan strategi pemasaran adalah penentuan media dan sarana penjualan. Sejauh ini, yang dilakukan adalah dengan membuat booth atau showcase khusus jamu tradisional. Pembuatan booth atau showcase ini bukan saja akan merubah citra penjualan jamu tradisional, namun diharapkan juga akan memperluas segmen dan meningkatkan volume penjualan.

2. Edukasi terhadap desain kemasan yang berorientasi pada perluasan segmen konsumen

Kunci utama untuk membuat sebuah desain kemasan yang baik adalah kemasan tersebut harus simple (sederhana), fungsional dan menciptakan respons positif. Daya tarik pada kemasan dapat digolongkan menjadi dua, yaitu daya tarik visual (estetika) dan daya tarik praktis (fungsional). Kemasan harus dapat menarik perhatian secara visual, emosional dan rasional. Sebuah desain kemasan yang bagus memberikan sebuah nilai tambah terhadap produk yang dikemasnya. Daya tarik visual sendiri berhubungan dengan faktor emosi dan psikologis yang terletak pada bawah sadar manusia. Sebuah desain yang baik harus mampu mempengaruhi konsumen untuk memberikan respons positif tanpa disadarinya. Sementara, daya tarik praktis merupakan efektivitas dan efisiensi suatu kemasan yang ditujukan kepada konsumen maupun distributor. Misalnya, untuk kemudahan penyimpanan atau pemajangan produk.

Sebagai dampak dari kegiatan edukasi strategi pemasaran, maka tampilan kemasan juga memerlukan penyesuaian. Setidaknya terdapat beberapa penyesuaian dalam kemasan yang perlu dilakukan dalam kaitannya dengan segmentasi pasar, diantaranya: penyesuaian ornamen identitas utama dan pelengkap produk (seperti logo, nama dan lain sebagainya), penyesuaian pengemasan produk, penyiapan kemasan pembungkus produk dan penyediaan informasi mengenai khasiat produk.

\section{METODE}

Metode pelaksanaan kegiatan pengabdian ini, secara umum terdiri dari 2 komponen utama, yaitu:

\section{Metode Ceramah dan Diskusi}

Metode ceramah dan diskusi dipergunakan untuk memberikan kerangka teoritis terkait permasalahan perluasan segmen pasar dan kaitannya dengan kemasan. Diskusi juga dilakukan dalam rangka pengembangan konsep kemasan dan 
pemasaran. Harapannya dengan diskusi yang berkelanjutan, pengusaha jamu tradisional dapat lebih memahami aspek strategis dalam hal pemasaran jamu tradisionalnya.

2. Metode Pendampingan

Pendampingan lebih diarahkan pada aktifitas yang berhubungan dengan keterampilan desain dan pemasaran dari desain itu sendiri. Setidaknya, terdapat empat kegiatan yang memerlukan pendampingan, diantaranya:

a. pendampingan dalam desain ornamen identitas produk

b. pendampingan dalam pengemasan produk

c. pendampingan dalam penyediaan informasi mengenai khasiat produk

d. Pendampingan dalam pemasaran dan penempatan booth/showcase penjualan

Proses produksi secara umum terbagi ke dalam 3 (tiga) tahapan utama, yaitu preproduksi dan produksi, pengemasan dan distribusi. Kegiatan pre-produksi, terdiri atas aktifitas penyediaan bahan baku dan aktifitas pembuatan jamu itu sendiri. Kegiatan pengemasan, merupakan kegiatan yang hanya berisikan aktifitas pengemasan sederhana ke dalam botol plastik ataupun kaca yang telah tersedia. Setelah jamu dimasukkan ke dalam botol, kemudian dilakukan aktifitas penyimpanan di dalam refrigerator. Proses berikutnya hanyalah tinggal menunggu konsumen melakukan pemesanan. Dalam lingkup penjualan yang masih terbatas, produk tersimpan yang tersedia di dalam refrigerator dibatasi tidak lebih dari 10 botol, jikalau dalam suatu hari tertentu terdapat lonjakan pemesanan, maka jamu akan langsung diproduksi saat itu juga.

Beberapa bentuk intervensi proses bisnis yang dilakukan berfokus pada kegiatan pengemasan, proses distribusi dan pemasaran. Terdapat beberapa titik kritis yang perlu dibenahi agar dapat meningkatkan volume produksi. Hal pertama yang direncanakan akan di benahi adalah berkaitan dengan perizinan usaha industri rumah tangga. Hal ini menjadi perlu untuk dilakukan, karena akan mengikat aktifitas-aktifitas distribusi dan pemasaran di tahapan berikutnya. Dalam kaitannya dengan kemasan, setidaknya ada beberapa kegiatan yang akan dilakukan diantaranya adalah pendampingan dalam hal desain ornamen identitas produk, pendampingan dalam hal desain dan pengemasan produk, pendampingan dalam desain hal kemasan pembungkus produk, pendampingan dalam hal penyediaan informasi mengenai khasiat produk dan cara terbaik dalam menikmati produk, pendampingan dalam hal desain dan penempatan booth penjualan

Kegiatan pengabdian dilaksanakan di tahun 2019, antara bulan Mei hingga bulan Agustus. Tempat pelaksanaan pengabdian, dilakukan di RW.14 Desa Cikadut, Kecamatan Cimenyan, Kabupaten Bandung.

\section{HASIL DAN PEMBAHASAN}

Secara umum, hasil dari pelaksanaan kegiatan pengabdian ini dapat ditinjau ke dalam empat aktifitas, yang diantaranya adalah:

1. Pendampingan dalam desain ornamen identitas produk

Secara umum desain ornamen identitas mengacu pada beberapa rekomendasi teoritis yang diungkapkan oleh Shimp, yang meliputi (Shimp, 2010): 
Rekomendasi Pertama: Penamaan harus memiliki identitas yang unik, yang membedakannya dengan merk produk kompetitif lainnya.

Rekomendasi kedua: Mudah diingat dan mudah diucapkan.

Kegagalan dalam memberikan identitas yang berbeda akan menciptakan kebingungan pada konsumen bahkan akan berdampak pada kemungkinan konsumen lupa dengan nama produk yang dikembangkan.

Dalam kaitannya dengan produk Jamu UTI, sejatinya identitas jamu UTI sudah cukup dikenal di lingkungan tempat penjual jamu tinggal. Nama "UTI" sendiri sebenarnya merupakan sebutan sederhana dari Eyang Putri. Sebutan Eyang Putri sendiri sebenarnya cukup lekat dalam budaya masyarakat Indonesia yang berlatar belakang suku Jawa (Amal, 2005). Panggilan ini biasa disematkan pada orang tua dari ayah dan/atau ibu. Secara penamaan, tidak ada yang diubah dari pelaksanaan pengabdian ini karena memang dirasakan sudah cukup memberikan representasi budaya jamu tradisional

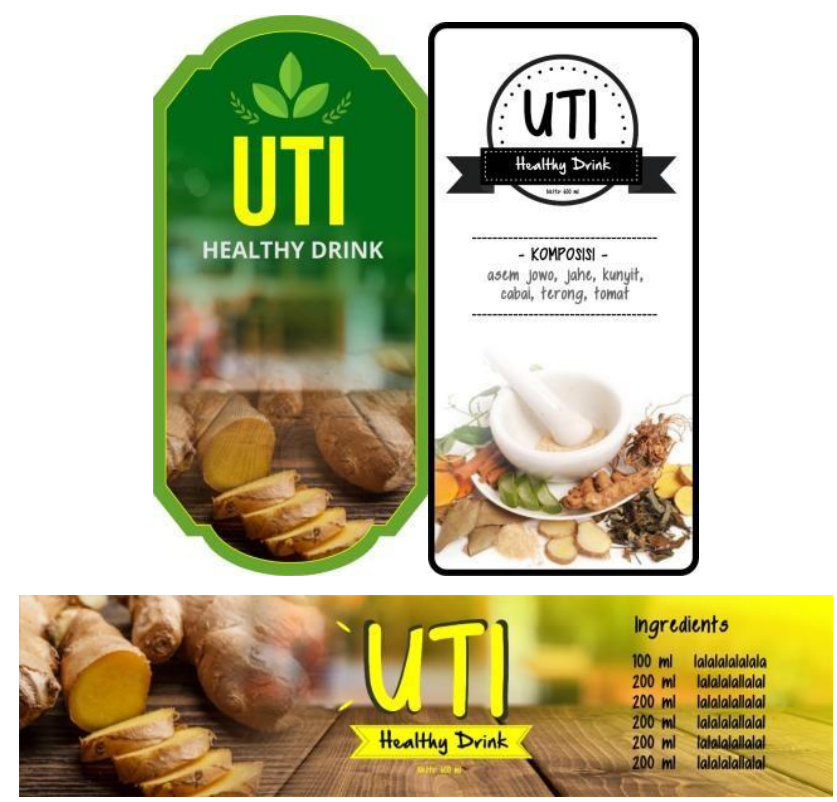

Gambar 1 Desain identitas produk Jamu UTI

Dalam kaitannya dengan produk Jamu UTI, sejatinya identitas jamu UTI sudah cukup dikenal di lingkungan tempat penjual jamu tinggal. Nama "UTI" sendiri sebenarnya merupakan sebutan sederhana dari Eyang Putri. Sebutan Eyang Putri sendiri sebenarnya cukup lekat dalam budaya masyarakat Indonesia yang berlatar belakang suku Jawa (Amal, 2005). Panggilan ini biasa disematkan pada orang tua dari ayah dan/atau ibu. Secara penamaan, tidak ada yang diubah dari pelaksanaan pengabdian ini karena memang dirasakan sudah cukup memberikan representasi budaya jamu tradisional.

Terkait dengan identitas lainnya, yaitu ornamen logo dan informasi produk, dilakukan beberapa pembenahan sederhana. Awalnya jamu UTI tidak memiliki identitas berupa gambar logo dan semacamnya. Konsumen membedakan rasa hanya dari informasi warna yang diberikan oleh penjual. Misalkan jika jamu berwarna agak kekuningan maka itu adalah jamu kunir asem, sementara jika sedikit berwarna coklat pucat maka itu adalah jamu beras kencur.

Pengabdian ini mengusulkan desain identitas berupa logo dan beberapa perubahan istilah. Istilah jamu, misalkan, diubah menjadi healthy drink. Perubahan istilah ini 
digunakan dengan harapan dapat mengubah mindset "jamu" yang cenderung terkesan produk tradisional menjadi produk minuman „kekinian". Gambar 1 manampilkan secara keseluruhan desain logo dan identitas dari jamu UTI.

Rekomendasi ketiga: Penamaan juga perlu memperhatikan sisi asosiatif yang akan aktif dalam memori konsumen. Dengan kata lain, penamaan dan identitas sebuah produk idealnya terbebas dari interpretasi yang tidak berkaitan dengan produk yang dihasilkan.

Dalam perjalanannya, identitas nama jamu UTI mengalamai perubahan nama. Hal ini dikarenakan sebutan "UTI" di beberapa daerah ternyata memiliki pengertian yang berbeda dan terkesan tidak wajar jika disematkan pada produk minuman. Oleh karenanya, desain logo dan identitas dikembalikan pada sebutan "Eyang Putri". Perubahan desain gambar dan logo ditampilkan oleh Gambar 2

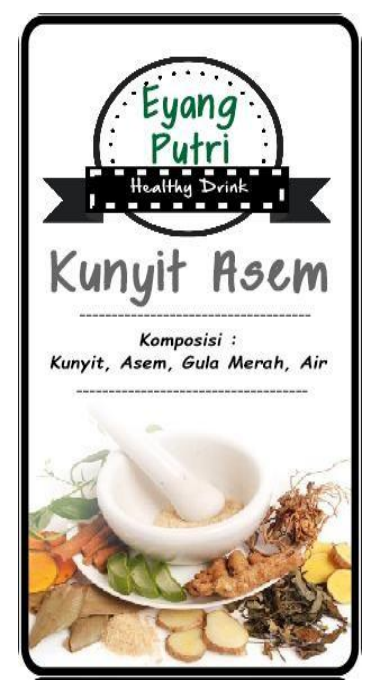

Gambar 2 Perubahan desain identitas produk Jamu UTI

Rekomendasi keempat adalah terkait kompatibilitas identitas gambar dengan kemasan dan pengemasannya. Desain ornamen gambar dan logo, menempatkan dominasi bahan khas jamu tradisional beserta media pembuatannya. Pemunculan ornamen ini diharapkan mampu mempertegas informasi terkait bagaimana produk Jamu UTI ini di produksi. Karena memang sejatinya penjual jamu UTI memproduksi jamunya dengan meninggalkan segenap bantuan teknologi yang mungkin membantu proses produksi, semisal blender dan memilih mengerjakannya secara manual.

\section{Pendampingan dalam pengemasan produk}

Untuk memberikan layanan pada konsumen, sekaligus sebagai media promosi terhadap produk Jamu UTI, dibuatlah kotak paket pembelian yang secara umum

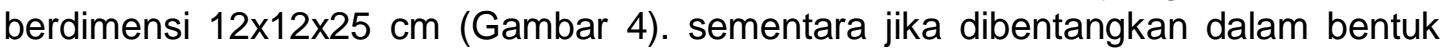
bidang (sebelum dilipat) maka dimensi kotaknya akan berukuran $82 \times 24 \mathrm{~cm}$ (Gambar 3).

Kotak kemasan didesain untuk menampung empat botol jamu UTI dengan kapasitas masing-masing botol 300-330 ml. Kapasitas kotak yang hanya berjumlah empat ini disesuaikan dengan variasi produk jamu yang juga berjumlah empat: Kunir Asem, Gula Asem, Beras Kencur dan Jahe Lemon Sereh. 


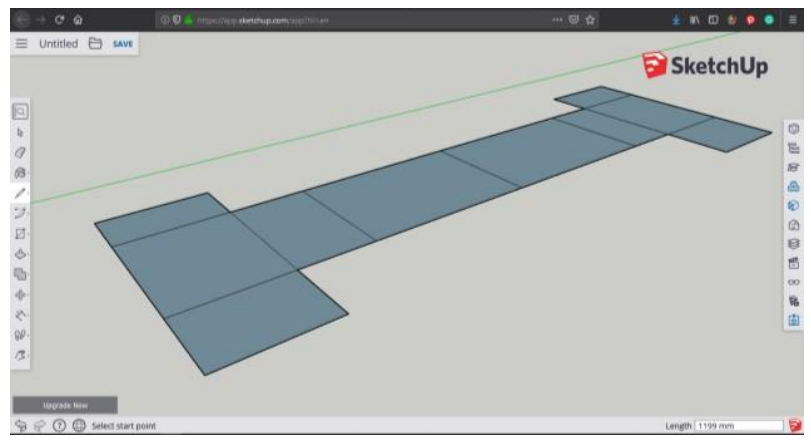

Gambar 3 Desain pengemasan produk Jamu UTI (sebelum dilipat)

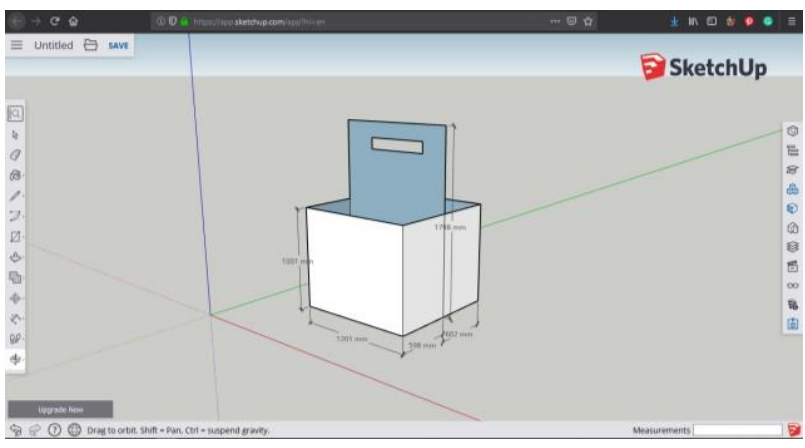

Gambar 4 Desain pengemasan produk Jamu UTI (sesudah dilipat)

Tabel 1 Beban biaya produksi kemasan

\begin{tabular}{|c|c|c|c|}
\hline $\begin{array}{c}\text { Bahan } \\
\text { Kertas }\end{array}$ & Ukuran & $\begin{array}{c}\text { Harga } \\
\text { Produksi }\end{array}$ & $\begin{array}{c}\text { Jumlah } \\
\text { Cetak }\end{array}$ \\
\hline $\begin{array}{c}\text { Kertas } \\
\text { kardus }\end{array}$ & $25 \times 50 \mathrm{~cm}$ & $\mathrm{Rp} 2.000,-$ & 50 unit \\
\hline
\end{tabular}

Tabel 1 menginformasikan beban biaya produksi kemasan yang sejatinya tidak terlalu memberatkan penjual jamu, mengingat omset penjualan yang cukup luar biasa. Pemesanan kotak dalam jumlah yang lebih banyak, tentunya akan lebih menekan biaya produksi.

3. Pendampingan dalam penyediaan informasi mengenai khasiat produk

Karena berhubungan dengan informasi yang bersifat umum, khasiat dari jamu yang diproduksi mengacu pada beberapa sumber-sumber digital dan tertulis yang kemudian ditulis ulang dengan melampirkan sumber informasi. Informasi khasiat ini ditempatkan di bagian luar kotak kemasan, dengan tujuan agar lebih mudah terbaca.

4. Pendampingan dalam pemasaran dan penempatan booth/showcase penjualan produk

Dalam kaitannya dengan pemasaran, selain melakukan pemasaran dengan cara yang sebelumnya: pemesanan secara langsung, baik melalui telpon atau langsung mendatangi penjual; dilakukan pula upaya perluasan pemasaran dengan menitipkan produk jamu pada penjual makanan Ayam Geprek. Secara kebetulan penjual Ayam 
Geprek ini berdomisili di lokasi yang tidak terlalu jauh dengan lokasi tempat tinggal penjual jamu UTI.

Penjualan jamu UTI di lokasi penjual Ayam Geprek dilakukan dengan menggunakan media Showcase. Karena lokasi penjualan Ayam Geprek yang memang berlokasi strategis di dekat kampus dan rumah tinggal di daerah Sarijadi. Pejualan jamu UTI pun mengalami perluasan segmen pasar sehingga menyasar pada segmen mahasiswa, wisatawan lokal dan internasional.

Meningkatnya jumlah penjualan dan omset penghasilan merupakan pencapaian pengabdian yang paling mungkin dibanggakan dari kegiatan pengabdian kemitraan masyarakat ini. Gambar 5 dan Gambar 6 menggambarkan perbandingan jumlah penjualan dan omset yang diperoleh sebelum dan sesudah dilaksanakannya pengabdian.

Data pada Garmbar 5 dan Gambar 6 diperoleh berdasarkan data penjualan yang tercatat di dua tahun terkahir, yaitu tahun 2018 dimana pengabdian belum dilakukan dan tahun 2019 dimana pengabdian sedang dilaksanakan; pada bulan yang sama yaitu Juni, Juli dan Agustus

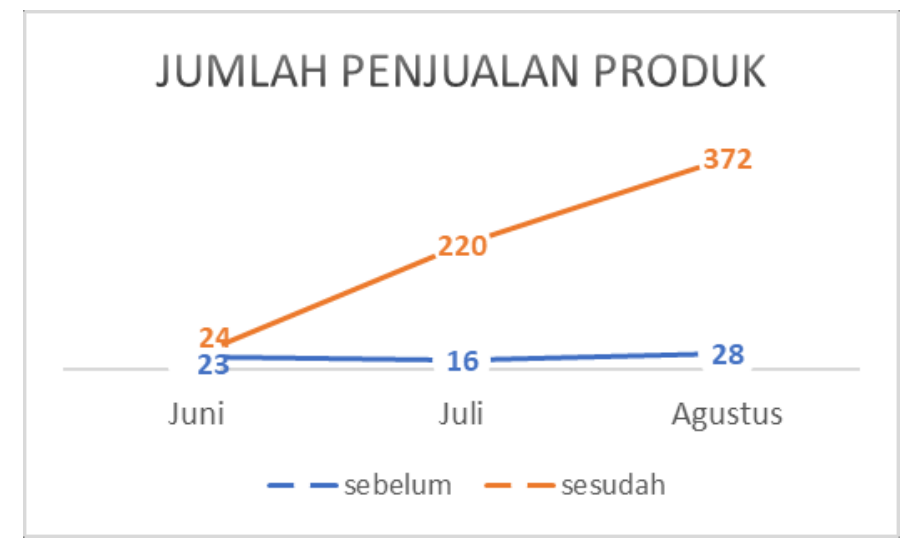

Gambar 5 Jumlah penjualan produk Jamu UTI

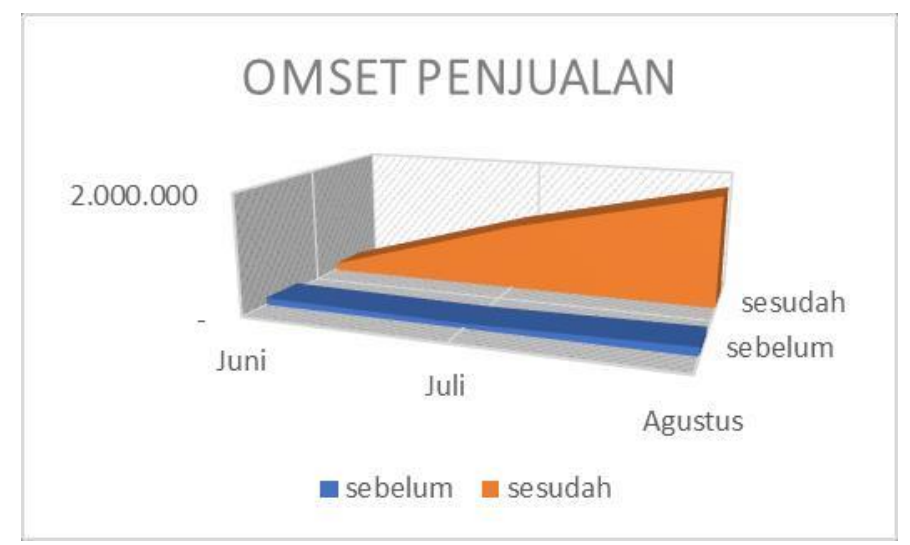

Gambar 6 Jumlah omset penjualan produk Jamu UTI

Skenario penjualan di tahun 2018 yang cenderung defensive, hanya mengandalkan pemesanan secara langsung tanpa melakukan ekspansi pasar, diduga menjadi penyebab stagnannya jumlah penjualan produk. Perubahan signifikan dalam manajemen proses bisnis berupa perubahan pola pemasaran dan desain kemasan 
„memaksa" pengusaha jamu UTI untuk bertaruh dengan produk yang dijual. Hasilnya, terjadi lonjakan dalam permintaan produk jamu. Peningkatan yang signifikan, tercatat terjadi pada bulan Agustus 2019 di mana hingga pekan ke-3 bulan tersebut nyaris 400 botol terjual. Omset penjualan pun meningkat tajam hingga ke angka Rp 1.860.000,(Gambar 6). Di bulan Juni, relatif belum terjadi perubahan signifikan. Hal ini disebabkan karena pengabdian ini masih dalam proses awal diskusi dan pengembangan kelengkapan instrumen perluasan pasar belum sepenuhnya tersedia. Selain tentunya juga dikarenakan bertepatan dengan pelaksanaan ibadah shaum Ramadhan. Di bulan Agustus peningkatan penjualan sudah mulai dirasakan. Pada bulan September, beberapa kali terjadi aksi borong produk oleh beberapa wisatawan lokal dan internasional yang kebetulan singgah ke lokasi penjualan.

Kendala terbesar yang muncul saat permintaan meningkat adalah kapasitas produksi pengusaha jamu sangat terbatas, sehingga belum cukup mampu memenuhi permintaan jamu secara keseluruhan. Karena memang dalam pengolahan jamu, pengusaha jamu UTI mengandalkan proses produksi secara manual dan relatif tanpa melibatkan mesin. Inilah mungkin yang menjadi keunggulan sekaligus keterbatasan dalam pengembangan produk jamu UTI. Selain itu, mungkin terbatasnya jumlah pekerja menjadi alasan lain dari minimnya kapasitas produksi pengusaha jamu UTI.

Dalam perkembangannya kami selaku pelaksana kegiatan pengabdian memotivasi pengusaha jamu UTI untuk berani membuka kios jamu mandiri. Secara kebetulan pengusaha jamu UTI berasal dari kota Semarang dimana terdapat satu kios jamu menarik di kota Semarang yang menjadi tempat nongkrong kalangan muda bernama BenStrong Wedang Rempah (Gambar 7) yang menyediakan berbagai jenis rempah untuk kemudian diolah menjadi minuman berkhasiat sepertihalnya jamu.

Desain kemasan dan perluasan segmen pasar penjualan jamu menjadi tantangan tersendiri bagi industri jamu. Dalam teori komunikasi pemasaran, setidak terdapat empat hal yang perlu mendapat perhatian dari produsen sebuah produk, diantaranya adalah (Shimp, 2010): 1) perlunya pendefinisian yang cukup definitif berkenaan dengan target pasar; 2) posisi produk jika dibandingkan dengan produk setipe lainnya; 3) apakah produk diciptakan untuk mencapai tujuan tertentu?; dan 4) idealnya proses komunikasi dilakukan untuk men-cover batasan anggaran yang ditetapkan. Dalam kasus jamu UTI, kemasan merupakan salah satu cara penjual jamu UTI untuk melakukan proses komunikasi pasar; di sisi lain, redesain kemasan akan menuntut pada perluaan segmen pasar.

Dalam tinjauan perilaku konsumen, persepsi konsumen akan sangat dapat dipengaruhi oleh stimulasi berulang. Kondisi ini jika terus berlanjut dapat berdampak pada daya saing. 


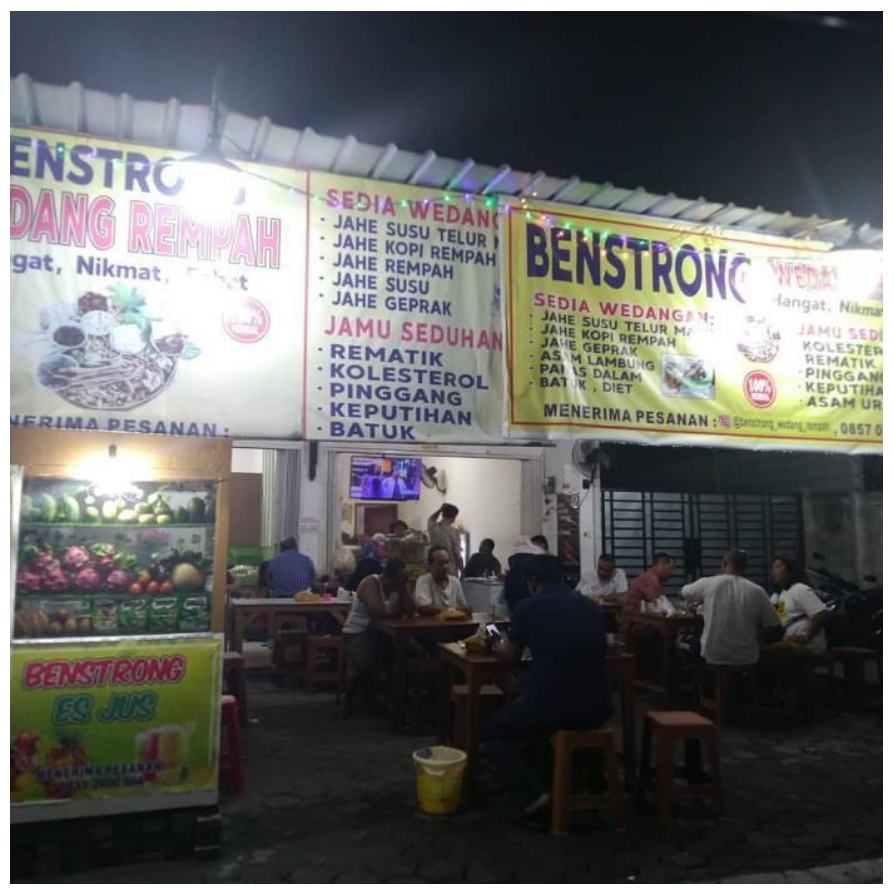

Gambar 7 Warung Jamu BenStrong, Semarang (sumber: http://picpanzee.com/place/168086270403257)

\section{KESIMPULAN}

Berdasarkan keseluruhan kegiatan yang telah dilakukan dalam pengabdian ini, beberapa kesimpulan yang dapat diperoleh adalah:

1. Keterbukaan pengusaha dalam mendiskusikan problematika penjualan menjadi penentu tercapainya beberapa luaran

2. Ketrampilan melakukan pengemasan dan pemasaran produk memberikan pengaruh secara signifikan pada peningkatan jumah penjualan produk dan omset yang diperoleh

3. Perluasan pasar perlu mempertimbangkan kapasitas produksi dari penjual jamu, karena kesalahan dalam memperkirakan kapasistas produksi akan berdampak pada terganggunya kesetimbangan antara permintaan dan pesediaan.

\section{UCAPAN TERIMAKASIH}

Terima kasih kami sampaikan sebesar-besarnya kepada Kementrian Riset Teknologi dan Pendidikan Tinggi, atas pendanaan kegiatan Pengabdian Kepada Masyarakat Program Kemitraan Masyarakat Tahun Pelaksanaan 2019. Demikian pula kepada Departemen Pendidikan IImu Komputer FPMIPA Universitas Pendidikan Indonesia untuk support program berkelanjutannya.

Terima kasih juga kami sampaikan kepada lbu Yayah Widiastuti selaku mitra pengabdian sekaligus pengusaha Jamu UTI yang berkenan berbagi pengalaman dan berbagi ide dalam pelaksanaan pengabdian kepada masyarakat ini. 


\section{DAFTAR PUSTAKA}

Amal, S. H. (2005). Menelusuri Jejak Kehidupan Keturunan Arab-Jawa di Luar Tembok Keraton Yogyakarta. ANTROPOLOGI INDONESIA, 29(2), 159-181.

Dean, A., \& McGuire, T. (2005). Herbal therapies and substance use. Drug and Alcohol Today, 5(2), 37 - 39.

Muslimin, L., Wicaksena, B., Setiyawan, B., Subekti, N. A., Suksesi, H., Surachman, H., ... Khaidir. (2009). Kajian Potensi Pengembangan Pasar Jamu. Pusat Penelitian dan Pengembangan Perdagangan Dalam Negeri, Badan Penelitian dan Pengembangan Perdagangan - Kementrian Perdagangan.

Natadjaja, L., Tripoli, F., \& Wahyono, B. (2013). Ethnicity as Identity in Packaging Design of Traditional Medicine (Jamu) for Women. International Conference and Summer School on Indonesian Studies. Yogyakarta. Retrieved from http://repository.petra.ac.id/16011/

Neubauer, I. L. (2012, February 29). TIME. Retrieved from Jamu: Why Isn't Indonesia's Ancient System of Herbal Healing Better Known?: http://content.time.com/time/world/article/0,8599,2107489,00.html

Nissen, N., \& Evans, S. (2012). Exploring the practice and use of Western herbal medicine: Perspectives from the social science literature. Journal of Herbal Medicine, 2(1), 6 - 15. doi:doi.org/10.1016/j.hermed.2012.02.001

Prabawani, B. (2017, March 25). Jamu Brand Indonesia: Consumer Preferences and Segmentation. Archives of Business Research, 5(3), 80 - 94. doi:10.14738/abr.53.2841

Shimp, T. A. (2010). Advertising, Promotion, \& Other Aspects of Integrated Marketing Communications (8th ed.). Canada: South-Western Cengage Learning.

Tari, R. (2015, Juni 25). Retrieved from Kompasiana - Beyond Blogging: https://www.kompasiana.com/bidancare/550e3312813311b72dbc60e5/penjualjamu-gunakan-botol-plastik-bekas-bahayakan-kesehatan 